\title{
Pattern of Waterborne Diseases in Yenagoa, Nigeria
}

\author{
"OHWO, O; OMIDIJI, AO
}

Department of Geography and Environmental Management, Niger Delta University, Wilberforce Island, Bayelsa State, Nigeria

"Corresponding Author Email: drohwodafe@gmail.com

\begin{abstract}
Waterborne diseases have negative implications on the health and socioeconomic activities of man. This paper analyzed the prevalence pattern of diarrhea and typhoid (DT) in Yenagoa. The study used data derived from responses to administered questionnaire on household's water, sanitation and hygiene (WASH) services and retrospective hospital data on recorded cases of DT in Yenagoa. Obtained data were analyzed with tables, percentages, analysis of variance (ANOVA) and T-test. The analyses showed that household's WASH provisions in Yenagoa were unsatisfactory and may have contributed to the incidence of both diseases. Those mostly impacted by both diseases were five years and below; while the dry season recorded higher cases, when safe water supply was more challenging. The ANOVA test showed that the monthly incidence of both DT do not significantly vary, as the calculated F-value for diarrhea was 6.865, $\mathrm{p}$-value, .135 ; while that for typhoid was, .590 , p-value, .842 at 0.05 alpha levels. However, the age and seasonal incidence of both DT varied significantly in Yenagoa. The ANOVA test for age distribution of diarrhea was F= 5.483 and p-value, .024 ; while that of typhoid was $\mathrm{F}=6.038$ and $\mathrm{p}$-value was .019 at 0.05 alpha levels. Similarly, the $\mathrm{t}$-test for seasonal incidence of diarrhea was $\mathrm{t}=4.836$ and $\mathrm{p}$-value, .005 ; while that of typhoid was $\mathrm{t}=4.468$ and $\mathrm{p}$-value, .007 at 0.05 alpha levels. Therefore, households should have unrestricted access to adequate WASH services, which act as primary barriers to the spread of DT diseases.
\end{abstract}

\section{DOI: https://dx.doi.org/10.4314/jasem.v25i6.20}

Copyright: Copyright $\odot 2021$ Ohwo and Omidiji. This is an open access article distributed under the Creative Commons Attribution License (CCL), which permits unrestricted use, distribution, and reproduction in any medium, provided the original work is properly cited.

Dates: Received: 20 March 2021; Revised: 27 April 2021; Accepted: 07 May 2021

Keywords: Diarrhea, typhoid, pattern, waterborne diseases, WASH.

Diarrhea and typhoid (DT), which are infections that are predominantly transmitted through contact with or consumption of infected water, exert major burden on human health in Nigeria. Waterborne diseases are initiated by different varieties of bacterial, viral, and protozoan pathogens found in faeces (Leclerc et al, 2002). These pathogens cause diarrhea typhoid, cholera, dysentery amongst others. These diseases are predominantly caused by the use of contaminated water, poor sanitation facilities and hygiene behaviour (WHO, 2019). These primary factors are major determinants of individual or household's susceptibility to waterborne diseases, which can however be aggravated by the poor level of an individual's income and educational status (Ohwo, 2019). DT have had severe negative impacts on people's health and socio-economic activities at household and national levels in most developing countries. Globally, an estimated 1.7 billion diarrhea infections are documented yearly among children, with a fatality of estimated 525,000 children who are five years or less. Although, diarrhea is treatable and preventable, it has caused malnutrition and fatalities among children who are five years and below (WHO, 2017). Also, about 22 million documented cases with 200,000 fatalities of typhoid are reported annually, worldwide (Crump et al, 2004). Although adequate WASH facilities have proven to be effective barriers to contracting infectious diseases, however, these services are poorly provided in Nigeria. For example, UNICEF and WHO (2019) recorded that in 2017, only $20 \%$ Nigerians used water sources that are safely managed, free from contamination and located on premises; while 7\% (over 13 million) Nigerians still depend on open water sources for most purposes. In addition, only $27 \%$ of Nigerians use sanitation that is safely managed; and open defecation (OD) was practiced by $20 \%$. Furthermore, only $42 \%$ Nigerians used basic hygiene facility on premises, a proxy for good hygiene behaviour (UNICEF and WHO, 2019). This probably explains why in Nigeria, an estimated 121, 800 persons, especially children below age five, die yearly from diarrhea, and these deaths are directly linked to poor WASH (Water and Sanitation Programme, 2012). Also, the socio-economic impacts exert financial burden, with serious impact on human development. For instance, due to diarrhea alone, Nigeria lose US\$2.5 billion each year to premature death, US\$ 13 million to losses in productivity while ill or accessing healthcare and US\$ 191 million associated direct and indirect cost on health seeking activities, with serious cost implications on 
households and government spending (WSP, 2012). In addition, waterborne diseases can cause malnutrition, growth retardation, stunting and cognitive disorder among children. Despite the huge negative impacts of these diseases on health and socio-economic activities, they continue to ravage many households in Yenagoa. To minimize the incidence of these diseases, it is pertinent to determine the risk factors and the pattern of these diseases prevalence in the city. Although WASH is known as primary driver of DT diseases, however, the pattern of both diseases is yet to be studied in Yenagoa. Therefore, this paper was aimed at the analysis of the pattern of DT in Yenagoa. This will provide the needed information to health authorities to plan effective intervention programmes to mitigate the incidence of DT in Yenagoa.

\section{MATERIALS AND METHODS}

Description of Study Area: Yenagoa was made the state capital of Bayelsa on its creation in 1996. It is situated between latitudes $4^{\circ} 55^{\prime}$ and $5^{\circ} 02^{\prime}$ north and longitudes $6^{\circ} 15^{\prime}$ and $6^{\circ} 25^{\prime}$ east (Figure 1) (Ohwo,
2019). Yenagoa is on lowland below 15 meters above sea level, which makes it highly susceptible to river flooding. Yenagoa is drained mainly by Ekole and Epie creeks and experiences the Koppen's Af climate classification, which is dominated by two seasonsrainy (wet) and dry (without rain), which are experienced in April - September and October March, respectively. The average yearly rainfall is about $4000 \mathrm{~mm}$, average monthly temperature of $28^{\circ} \mathrm{C}$ and average relative humidity of about $70 \%$. Yenagoa has grown rapidly from about 50,000 persons in 1991 to a projected population of about 350,000 in 2019 because of its status as state capital. Despite the high population of Yenagoa, infrastructural facilities such as housing, roads and WASH facilities are poorly provided (Ohwo, 2019), which has forced some people to use contaminated water. The dependence on unimproved WASH facilities could compromise people's health and make them vulnerable to waterborne diseases. Therefore, this paper was designed to analyze the pattern of DT in Yenagoa, to address the existing gap in knowledge.

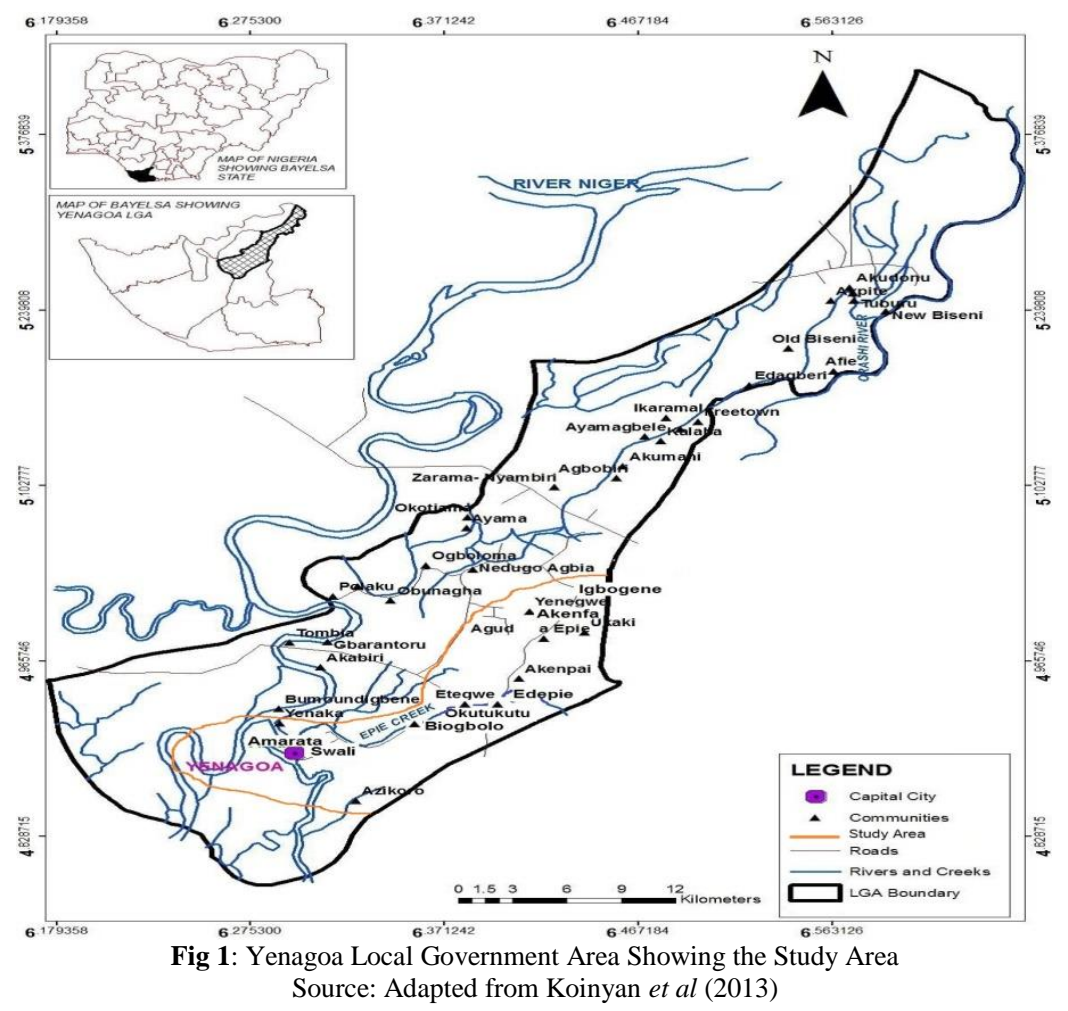

Data Collection and Treatment: The survey and retrospective research designs were adopted; which include physical observation of respondents WASH facilities and the administration of questionnaire and retrospective hospital records on DT cases in Yenagoa. The study population was all the entire households in Yenagoa, which comprises of 87,500 households, using the 2019 projected population of 350,000 and four persons per household (Ohwo, 2019). To achieve an adequate sample, the multi-stage sampling was adopted. Firstly, Yenagoa was structured into four zones (each comprises of five communities). Secondly, using the systematic sampling method, 100 households each were selected, 
respectively from the four zones, making 400 households. The sample was considered adequate using the Krejcie and Morgan (1970) equation " $[\mathrm{S}=$ $\left.\mathrm{X}^{2} \mathrm{NP}(1-\mathrm{P}) \div \mathrm{d}^{2}(\mathrm{~N}-1)+\mathrm{X}^{2} \mathrm{P}(1-\mathrm{P})\right]$ for sample determination of a population, where: $S$, is required sample size; $\mathrm{X}^{2}$, chi-square table value @ d.f = 1 for desired confidence level; $\mathrm{N}$, the population size; $\mathrm{P}$, the population proportion, taken as 0.50 ; and $\mathrm{d}$, the accuracy level given as a proportion $(0.05)$ ". The data were obtained from secondary and primary sources. The primary data was from responses to a set of 400 questionnaires, which was administered directly by hand to respective sampled household head. The questionnaire has two sections-A and B. Section A addresses demographics of respondents, while Section B focused on responses to households WASH services, which were considered as major determinants for DT infections. The JMP ladder for monitoring global services of WASH was used to examine WASH services of households. The secondary data, which comprise of documented hospital records of DT in Yenagoa for three consecutive years-2016, 2017 and 2018 were gotten from the Ministry of Health, Yenagoa.

Data Analysis: The data obtained were analyzed using tables, frequencies, percentages, T-test and ANOVA. T-test was used to test whether there was significant difference in the seasonal (rainy and dry) occurrence of DT, respectively in Yenagoa; while ANOVA was used to test whether there were significant monthly and age variations in the incidence of DT, respectively in Yenagoa. Both tests were done with SPSS software, version 22 .

\section{RESULTS AND DISCUSSION}

Demographics of Respondents: The demographics of respondents were obtained from section $\mathrm{A}$ of the administered questionnaire and presented in Table 1. Of the 400 administered questionnaires, 396 (99\%) were retrieved and analyzed. The sex distribution reveals that male responses were 191 (48.2\%), while female responses were $205(51.8 \%)$. This shows that the views of both genders were adequately represented. Responses to age bracket indicate that 2540 years old respondents had the most responses of $181(45.7 \%)$; while the lowest, 19 (4.8\%) was above 65 years old. The age structure seems youthful, as $70.7 \%$ of the responses were from respondents who are 40 years and below. This age bracket constitutes a significant proportion of the productive class, which may create great challenges to the socio-economic activities of Yenagoa if the health of this age range is compromised. Responses to marital position show that $233(58.8 \%)$ were married, while 149 (37.6\%) and 14
(3.5\%), were single and others (divorce, widowed and widowers) respectively. The 1-3 household size had the most responses of 152 (38.4\%), while the lowest, $38(9.6 \%)$ was for above 9 persons. Furthermore, 244 $(61.6 \%)$ respondents had a household size of 4 persons and above, which may increase infection rates in case of a disease outbreak, especially when the affected household has poor WASH services. The occupational structure shows that $170(42.9 \%)$ respondents were self-employed, while 59 (14.9\%), $139(35.1 \%)$ and 28 $(7.1 \%)$, were public servants, private/business and others respectively. Although the educational and income statuses of individuals influence their susceptibility to waterborne diseases, however, only $32.6 \%$ of the responses indicated tertiary education, while $67.4 \%$ had below tertiary education. This means that most households may be susceptible to waterborne diseases, as the NPC and ICF International (2014) asserted that children who have uneducated mothers are more predisposed to diarrhea than children whose mothers have tertiary education. Similarly, Yilgwan and Okolo (2012) also reported that a significant relationship exist between mother's educational levels with the rate of diarrhea infection in children. The respondents' educational levels mirror their income levels in Yenagoa. The income bracket that had the most responses, $202(51 \%)$ was below $\mathrm{N} 30,000$ (US\$79) per month, while the lowest, 31 (7.8\%) was above $\mathrm{N} 250,000$ (US\$660) per month. In all, $328(82.8 \%)$ of the responses indicated N100,000 (US\$264) and below. This income structure shows that most household heads in Yenagoa could be regarded as low or middle income earners. Therefore, WASH services to these categories of households may be low as UNICEF and WHO (2019) noted that wealth influences access to WASH services, which are primary causes of DT diseases. Since NPC and ICF International (2014) asserted that there exists a relationship between family wealth and diarrhea infections, therefore, children of poor parents in Yenagoa may be more predisposed to diarrhea disease than their rich counterparts.

\section{Households Wash Status in Yenagoa}

Drinking water sources: UNICEF and WHO (2015) indicated that a household's major water source is usually adopted as proxy for safe water supply because of the difficulties involved in testing continuously the quality of each household's drinking water supply. Hence, respondents were asked the source of their major drinking water, using the WHO and UNICEF (2017) JMP ladder for WASH services. The responses revealed that only $79(19.9 \%)$ of the responses indicated access to safely managed drinking water sources (Table 2). This figure is approximately the same with the national average of $20 \%$ in 2017 , but far 
below the sub Saharan Africa (SSA) and global averages of $21 \%$ and $71 \%$, respectively (UNICEF and WHO, 2019). This shows that water sources that are safely managed in Yenagoa and Nigeria in general is grossly inadequate. Households that have water sources that are safely managed are least susceptible to DT diseases. Unfortunately, $80.1 \%$ of respondents used either basic, 190 (48\%), limited, 66 (16.7\%), unimproved, $41(10.4 \%)$ or surface water, $20(5 \%)$, respectively. The water quality from these sources is not guaranteed and is vulnerable to quality degradation, which make them unsafe for human consumption. The high number of respondents not using water sources that are safely managed shows that affected households may be at risk of consuming contaminated water and increase the probability of contracting DT diseases. Despite this situation, an estimated $70 \%$ of households in Yenagoa hardly treat their drinking water before consumption (Koinyan et al, 2013), which further increases the existing risk of contracting DT diseases in Yenagoa.

Table 1: Respondents Demographic Characteristics

\begin{tabular}{|c|c|c|c|}
\hline $\begin{array}{l}\text { Questionnaire } \\
\text { Variable }\end{array}$ & $\begin{array}{l}\text { Response } \\
\text { Variable }\end{array}$ & $\begin{array}{l}\text { No of } \\
\text { Respondents }\end{array}$ & Percentage \\
\hline \multirow[t]{2}{*}{ Sex } & Male & 191 & 48.2 \\
\hline & Female & 205 & 51.8 \\
\hline \multirow[t]{4}{*}{ Age } & Below 25 years & 99 & 25.0 \\
\hline & $25-40$ years & 181 & 45.7 \\
\hline & $41-65$ years & 97 & 24.5 \\
\hline & Above 65 years & 19 & 4.8 \\
\hline \multirow[t]{3}{*}{ Marital Status } & Married & 233 & 58.8 \\
\hline & Single & 149 & 37.6 \\
\hline & Others & 14 & 3.5 \\
\hline \multirow[t]{4}{*}{ Household Size } & $1-3$ & 152 & 38.4 \\
\hline & $4-6$ & 145 & 36.6 \\
\hline & $7-9$ & 61 & 15.4 \\
\hline & Above 9 & 38 & 9.6 \\
\hline \multirow[t]{4}{*}{ Occupation } & Self employed & 170 & 42.9 \\
\hline & Public service & 59 & 14.9 \\
\hline & Private/Business & 139 & 35.1 \\
\hline & Others & 28 & 7.1 \\
\hline \multirow{4}{*}{$\begin{array}{l}\text { Educational } \\
\text { Qualification }\end{array}$} & formal & 77 & 19.4 \\
\hline & edu/Primary & & \\
\hline & Secondary & 190 & 48.0 \\
\hline & Tertiary & 129 & 32.6 \\
\hline \multirow{4}{*}{$\begin{array}{l}\text { Monthly } \\
\text { Income }\end{array}$} & Below N30, 000 & 202 & 51.0 \\
\hline & $\begin{array}{l}\text { N30, } 000-\mathrm{N} 100 \\
000\end{array}$ & 126 & 31.8 \\
\hline & $\begin{array}{l}\text { N100,000 - N250, } \\
000\end{array}$ & 37 & 9.3 \\
\hline & Above N250, 000 & 31 & 7.8 \\
\hline
\end{tabular}

Used Sanitation Facilities: Although the sanitation facility used by households may determinant the probability of contracting DT, its provision in Yenagoa, other parts of Nigeria and SSA is grossly inadequate and far below water provision. Table 2 revealed that only $52(13.1 \%)$ of the responses indicated using safely managed sanitation facilities. This figure is far below the averages documented by UNICEF and WHO (2019) for Nigeria (27\%), SSA $(18 \%)$ and the world (45\%); but higher than the average for Niger Republic (10\%) in 2017. In addition, $40(10 \%)$ of the households still practices open defecation (the worst form of sanitation). Since 186 (46.9\%) of the responses indicated using limited sanitation $(25 \%)$, unimproved sanitation $(11.9 \%)$ or open defecation (10\%), it is highly probable that water sources (surface water and groundwater) may be polluted by human faeces through runoffs, as these sanitation amenities do not guarantee proper disposable of human faeces. This situation coupled with water supply from unsafe sources in Yenagoa, may pose serious threat to public health.

Used Hygiene Facilities: Since the presence of hygiene facilities correlate significantly with hygiene practice (Yallew et al, 2012) and the inability to continuously monitor each household's hygiene behaviour, having hygiene facilities was adopted as proxy for good hygiene behaviour amongst households. Good hygiene practice is an effective barrier to the spread of diarrhea and could reduce its prevalence up to $45 \%$ (Fewtrell et al, 2005). Similarly, UNICEF and PHG (2010) in their study in Gaza, noted that at least a child below five years in one of five 
surveyed households (20\%) had contracted diarrhea four weeks before being surveyed because of poor hygiene and inadequate water quality. This shows that hygiene is a risk factor to contracting DT diseases. Therefore, households with poor hygiene may have higher probability to contract DT. Despite this reality however, responses on households' used hygiene facilities as presented in Table 3 revealed that 192
(48.5\%) households used either limited, 110 (27.8\%) or have no hygiene facilities, 82 (20.7\%); while 204 $(51.5 \%)$ households used basic hygiene. Although the hygiene facilities among households were unsatisfactory, however, households with basic hygiene services were higher than the average of $42 \%$ for Nigeria and $25 \%$ for SSA; but less than the world average of $60 \%$ (UNICEF and WHO, 2019).

Table 2: Households' WASH Status in Yenagoa

\begin{tabular}{|c|c|c|c|}
\hline $\begin{array}{l}\text { Questionnaire } \\
\text { Variable }\end{array}$ & $\begin{array}{l}\text { Response } \\
\text { Variable } \\
\end{array}$ & Respondents & Percentage \\
\hline \multicolumn{4}{|l|}{$\begin{array}{l}\text { Drinking water } \\
\text { sources }\end{array}$} \\
\hline & Safely managed & 79 & 19.9 \\
\hline & Basic & 190 & 48.0 \\
\hline & Limited & 66 & 16.7 \\
\hline & Unimproved & 41 & 10.4 \\
\hline & Surface Water & 20 & 5.0 \\
\hline \multicolumn{4}{|l|}{$\begin{array}{l}\text { Sanitation } \\
\text { facilities }\end{array}$} \\
\hline & Safely Managed & 52 & 13.1 \\
\hline & Basic & 158 & 40.0 \\
\hline & Limited & 99 & 25.0 \\
\hline & Unimproved & 47 & 11.9 \\
\hline & Open defecation & 40 & 10.0 \\
\hline \multicolumn{4}{|l|}{$\begin{array}{l}\text { Hygiene } \\
\text { facilities }\end{array}$} \\
\hline & Basic & 204 & 51.5 \\
\hline & Limited & 110 & 27.8 \\
\hline & No facility & 82 & 20.7 \\
\hline
\end{tabular}

Pattern of DT Prevalence in Yenagoa: The three years (2016, 2017 and 2018) consecutive data on DT, gotten from the Public Health Department, Ministry of Health, Yenagoa, Bayelsa State, as presented in Table 4 were used to analyze the pattern of DT prevalence in Yenagoa.

Monthly pattern of DT prevalence: From Table 3, the monthly range of typhoid prevalence for 2016 (0-216), 2017 (13-87) and 2018 (0-130) occurred in August and October, June and February, and June, December and November, respectively. This shows that the monthly incidence of typhoid in Yenagoa was erratic and did not follow any regular pattern, which was similar to the findings by (Corner et al, 2013). In this study, the total incidence of typhoid and prevalence rate (per 100,000 persons) for each year $(2016,2017$ and 2018) decreased progressively from 868 (248) to 471 (134.6) and 468 (133.7), respectively. This is at variance with a study in Ghana, by Fusheini and Gyawu (2020). In this study the mean total cases for the three years was 602.3 , with an average occurrence rate of 172.1 per 100,000 persons. This figure was higher than the annual 107 prevalence rate recorded in Nikoko, but lower than the 402 occurrences per 100,000 persons recorded in Polesgo, both in Burkina Faso (Ghenghensh et al 2009). The average monthly cases and occurrence rate for the three years $(2016,2017$ and 2018) range from $13.3(2.2 \%)$ to $90(14.9 \%)$; with August having the lowest value, while January had the highest. The ANOVA test shows that $\mathrm{F}=.590$, p-value $=.842$ (which is higher than the 0.05 alpha level), which means there was no significant variation in the monthly incidence of typhoid in Yenagoa. The monthly range of diarrhea for the three consecutive years, 2016 (48-333), 2017 (46-589) and 2018 (0-119) were documented in the months of February and January, December and March, and September and July, respectively. In 2016 and 2017, both the most and least figures were documented in the season without rain, while in 2018; both the most and least figures were documented in the wet season. Similar to typhoid, the total diarrhea cases for the three consecutive years reduced progressively from 1,963 (2016) to 1,760 (2017) and 556 (2018). However, the average yearly total cases for diarrhea were 1,426.3, with an average monthly range of 66.7 (September) to 298 (March) cases, and a mean occurrence rate of 407.5 per 100,000 persons. When compared with typhoid, more diarrheas were recorded for the three years. For example, in 2016, 868 and 1,963 cases were reported, for typhoid and diarrhea respectively; with similar trends also recorded for 2017 (471 \& 1,760) and 2018 (468 \& 556). This shows that the impact of 
diarrhea was more than typhoid in Yenagoa. The ANOVA test shows that $\mathrm{F}=6.865$, $\mathrm{p}$-value $=.135$ (which is higher than the 0.05 alpha level), which means there was no statistically significant variation in the monthly diarrhea incidence in Yenagoa.

Table 3: Monthly Pattern of DTPrevalence in Yenagoa, 2016-2018

\begin{tabular}{|c|c|c|c|c|c|c|c|c|c|}
\hline \multirow[t]{2}{*}{$\mathbf{S} / \mathbf{N}$} & \multirow[t]{2}{*}{ Month } & \multicolumn{4}{|c|}{ Typhoid fever } & \multicolumn{4}{|c|}{ Diarrhea } \\
\hline & & 2016 & 2017 & 2018 & Mean $(\%)$ & 2016 & 2017 & 2018 & Mean $(\%)$ \\
\hline 1 & January & 125 & 45 & 100 & $90(14.9)$ & 333 & 75 & 56 & $154.6(10.8)$ \\
\hline 2 & February & 49 & 87 & 19 & $51.7(8.6)$ & 48 & 156 & 32 & $78.7(5.5)$ \\
\hline 3 & March & 116 & 25 & 27 & $56(9.3)$ & 231 & 589 & 74 & $298(20.9)$ \\
\hline 4 & April & 63 & 85 & 46 & $64.7(10.7)$ & 275 & 261 & 69 & $201.6(14.1)$ \\
\hline 5 & May & 41 & 57 & 30 & $42.7(7.1)$ & 129 & 105 & 38 & $90.7(6.4)$ \\
\hline 6 & June & 79 & 13 & 0 & $30.7(5.1)$ & 150 & 87 & 44 & $93.7(6.6)$ \\
\hline 7 & July & 19 & 38 & 41 & $32.7(5.4)$ & 171 & 105 & 119 & $131.7(9.2)$ \\
\hline 8 & August & 0 & 24 & 16 & $13.3(2.2)$ & 109 & 69 & 27 & $68.3(4.8)$ \\
\hline 9 & September & 41 & 32 & 37 & $36.7(6.1)$ & 134 & 66 & 0 & $66.7(4.7)$ \\
\hline 10 & October & 216 & 24 & 22 & $87.3(14.5)$ & 89 & 123 & 8 & $73.3(5.1)$ \\
\hline 11 & November & 47 & 15 & 130 & $64(10.6)$ & 101 & 78 & 37 & $72(5.0)$ \\
\hline 12 & December & 72 & 26 & 0 & $32.7(5.4)$ & 193 & 46 & 52 & $97(6.8)$ \\
\hline 13 & Total & 868 & 471 & 468 & $602.3(100)$ & 1963 & 1760 & 556 & $1426.3(100)$ \\
\hline 14 & Prevalence (per 100, 000) & 248 & 134.6 & 133.7 & 172.1 & 560 & 502.9 & 158.9 & 407.5 \\
\hline
\end{tabular}

Seasonal pattern of DT in Yenagoa: Table 4 showed that more typhoid occurrences were documented in the dry season. For example, 1,145 typhoid incidences were documented in the dry season for the three years (2016, 2017 and 2018) under review, as against 662 documented incidences in the rainy season. The yearly mean total typhoid cases in the dry season was 381.7 $(63.4 \%)$, while 220.7 (36.6\%) for the wet season. The probable reason for this pattern is that due to the regular rains in the wet season, households with poor water sources, harvest rain water, which quality may be higher than other unimproved water sources. This reduces the likelihood of consuming polluted water during the wet season as opposed to the dry spell season, when improved water sources becomes a challenge and households are compelled to get water from questionable sources, which may have been contaminated. In addition, the availability of 'free water' during the wet season may also promote frequent hand washing and improve sanitation, which are effective barriers to DT diseases. The average monthly typhoid cases peaked in January-April and October-November, where $43.5 \%$ and $25.1 \%$ of all the cases were recorded (see Table 3). This trend differs from a study in Dhaka, Bangladesh, where the highest monthly typhoid incidences were documented in JulyOctober and April-June (Corner et al, 2013). Hence, Saad et al (2018) asserted that the inability to achieve consistent and strong association of typhoid prevalence with rainfall and/or temperature indicated that the various environmental drivers and pathway of transmission may vary by setting and be influenced by other factors and that the difference in disease in the equatorial region might be caused partly due to variations in temperature. This indicates that the incidence of typhoid in Yenagoa was influenced by the seasons, as the t-test reveals that there exists a significant difference in the seasonal cases of typhoid in Yenagoa, with a $t=4.468$ and $p$ - value of .007 (which was lower than the 0.05 alpha level). Although past studies have indicated that diarrhea prevalence coincide with rainy season in parts of Africa (Morse et $a l, 2007)$ however, it has been established that certain enteric pathogens, such as Escherichia coli and Cryptosporidium species, peak in incidence in the rainless season when safe water becomes less available. This probably explains why more diarrhea cases were documented in the rainless season (Table 4). The seasonal pattern of diarrhea was similar to that of typhoid, as more diarrhea cases were documented in the rainless season than the wet season. For example, except 2018, more diarrhea cases were documented in the rainless season for 2016 (995) and 2017 (1067). The total diarrhea prevalence in the rainless season for the three years $(2016,2017$ and 2018) under review was 2,321 , while 1,958 for the wet season, with a yearly mean cases of $773.7(54.2 \%)$ for the rainless season and $652.7(45.8 \%)$ for the wet season.

Table 4: Seasonal Pattern of DT in Yenagoa, 2016-2018

\begin{tabular}{llllllllll}
\hline S/N & Season & \multicolumn{3}{c}{ Typhoid } & \multicolumn{3}{c}{ Diarrhea } \\
\hline & & 2016 & 2017 & 2018 & Mean $(\%)$ & 2016 & 2017 & 2018 & Mean $(\%)$ \\
\hline 1 & Dry & 625 & 222 & 298 & $381.7(63.4)$ & 995 & 1067 & 259 & $773.7(54.2)$ \\
2 & Rainy & 243 & 249 & 170 & $220.7(36.6)$ & 968 & 693 & 297 & $652.7(45.8)$ \\
3 & Total & 868 & 471 & 468 & $602.4(100)$ & 1963 & 1760 & 556 & $1426.4(100)$ \\
\hline \multicolumn{3}{c}{ Source: Department of Public Health, Ministry of Health, Bayelsa State (2020) }
\end{tabular}


This trend confirmed the WHO report as cited in Ahmed et al (2008) that in the tropics, rotavirus diarrhea occurs the year round, increasing in rate in the drier, cool months, whereas bacterial diarrhea peak in the warmer, wet season. The t-test indicates that there was a statistically significant difference in the seasonal incidence of diarrhea in Yenagoa, as the t-value was 4.836 and p-value was .005 (which was $<0.05$ alpha levels).

Age pattern of DT in Yenagoa: From Table 5, the age pattern of typhoid shows that children $<5$ years had the most mean annual cases of 335.7; while 5-9years had the lowest mean annual cases of 46. These translate to $55.7 \%$ and $7.6 \%$ of all reported cases. After the drastic reduction in the mean recorded cases for children 5-9years, the mean cases increased to 124 (20.6\%) between 10-40years, and reduced further to $96.7(16.1 \%)$ among 40 years old and above. The probable reason for the high reported cases among children below five years was because of the usual low immunity of children within this age bracket, hence they were more susceptible to infectious diseases. This explains why the highest average annual occurrence rate of typhoid cases (95.9) per 100,000 was recorded for children < 5; while the lowest mean annual prevalence rate of 13.1 was recorded for children aged 5-9years. The probable reason for the sharp decrease of typhoid in this age bracket may be due to better appreciation of hygiene (washing of hands), adaptation to the environment and improved immunity. The typhoid prevalence rates in this study were lower than the one reported in a study in Hohoe municipality, Volta Region, Ghana, where the incidence of typhoid was highest among children between the ages of 2-5years, with an annual prevalence rate of 290 per 100,000 persons (Fusheini, and Gyawu, 2020). However, other studies of typhoid incidence in Indonesia, Pakistan and India, reported annual prevalence rates of $180.3,412.9$ and 493.5 per 100,000 persons respectively, among children between the ages of 5-15years old (Ochiai et al, 2008).
This shows that there is spatial variation in the prevalence of typhoid in different regions. In this study, children < 5years had the highest reported cases of 473, 312 and 222, respectively for 2016, 2017 and 2018. This shows that typhoid is highest among children of this age category in Yenagoa. This was buttressed by the ANOVA analysis which shows that there was a statistically significant variation in the age distribution of typhoid in Yenagoa, as the F-value was 6.038 and p-value was .019 (which was < 0.05 alpha level). Similar to typhoid, data on age distribution of diarrhea as presented in Table 6 revealed that the highest number of cases for the three years under review occurred among children $<5$ years. Out of the recorded cases of 4,279 , children $<5$ years were 2,752 $(64.3 \%)$; with a mean annual recorded cases of 917.3 and an annual prevalence rate of 261.1 per 100,000 persons. These figures are not surprising because it has been documented in the literature that diarrhea is one of the major killers of under five years in the world. For example, in Nigeria, out of the estimated 121,800 deaths annually from diarrhea, 87,100 (71.5\%) were children < 5years, and $90 \%$ of the deaths were directly attributed to inadequate WASH services (Water and Sanitation Programme, 2012). In this study, the diarrhea prevalence rate decreased substantially from 262.1 per 100,000 persons per annum among children below 5years to 57.1 per 100,000 persons per annum at 5-9years and decreased further to 40 per 100,000 persons at $10-40$ years and rose to 48.3 per 100,000 persons at above 40years. This pattern of diarrhea prevalence may be due to a higher appreciation of hygiene and improved immunity to diseases among those between 5-40years. The total number of recorded diarrhea cases during the three years period had experience a downward trend, from 1,963 (2016);1,760 (2017) to 556 (2018), The ANOVA analysis shows that the F-value was 5.483 and p-value was .024 (which was $<0.05$ alpha level). This means that there was a significant variation in the age prevalence of diarrhea in Yenagoa.

Table 5: Age Distribution of Typhoid Fever and Diarrhea in Yenagoa, 2016-2018

\begin{tabular}{|c|c|c|c|c|c|c|c|c|c|c|c|}
\hline $\mathbf{S} / \mathbf{N}$ & Age & \multicolumn{5}{|c|}{ Typhoid Fever } & \multicolumn{5}{|c|}{ Diarrhea } \\
\hline 2 & $5-9$ yrs & 19 & 62 & 57 & $46(7.6)$ & 13.1 & 280 & 174 & 146 & $200(14.0)$ & 57.1 \\
\hline 3 & $10-40 \mathrm{yrs}$ & 257 & 56 & 59 & $12420.6)$ & 35.4 & 223 & 189 & 8 & $140(9.8)$ & 40 \\
\hline 4 & Above 40 yrs & 119 & 41 & 130 & 96.7 16.1) & 27.6 & 294 & 124 & 89 & $169(11.8)$ & 48.3 \\
\hline
\end{tabular}


Conclusion: The study has revealed that the inhabitants of Yenagoa have poor access to WASH services, which predisposed them to DT diseases. Also, higher number of DT where recorded during the dry season, when access to WASH services were more challenging. The study further confirmed that children who are five years and less bear more burden of DT due to their lower immunity. Therefore, households should have unrestricted access to adequate WASH services, which act as barriers to the transmission of both diseases, which should be followed by WASH education.

\section{REFERENCES}

Ahmed, SF; Farheen, A; Muzaffar, A; Mattoo, GM (2008). Prevalence of diarrhoeal disease, its seasonal and age variation in under-fives in Kashmir, India. Int. J. Health Sci. 2 (2): 126-133

Corner, RJ; Dewan, AM; Hashizume, M (2013). Modeling typhoid risk in Dhaka metropolitanarea of Bangladesh: the role of socio-economicand environmental factors. Int. J. Health Geogr. 12:13: $1-15$

Crump, JA; Luby, SP; Mintz, ED (2004). The global burden of typhoid fever. Bulletin of the World Health Organization.Int. J. Public Health 82(5) : 346-353

Fewtrell, L; Kaufmann, RB; Kay, D; Enanoria, W; Haller, L; Colford Jr., JM (2005). Water, sanitation and hygiene interventions to reduce diarrhoea in less developed countries: a systematic review and meta-analysis. Lancet Infect. Dis. 5, 42-52.

Fusheini, A; Gyawu, SK (2020). Prevalence of typhoid and paratyphoid fever in the Hohoe municipality of the Volta Region, Ghana: A fiveyear retrospective trend analysis. Ann. Glob. Health. 86 (1): 111, 1-10

Ghenghensh, KS; Franca, E; Tawil, K; Wasfy, MO; Ahmed, SF; Rubino, S; Klena, JD (2009).Enteric fever in Mediterranean North Africa. J Infect Dev. Ctries. 3: 753-761.

Koinyan, AA; Nwankwoala, HO; Eludoyin, OS (2013). Water resources utilization in Yenagoa, Central Niger Delta: Environmental and health implications. Int. J. Water Res. Environ. Eng. 5 (4), 177-186

Krejcie, RV; Morgan, DW (1970). Determining Sample Size for Research Activities. Educ. Psychol. Measure, 1970.30: 607-610.
Leclerc, H; Schwartzbrod, L; Dei-Cas, E (2002). Microbial agents associated with waterborne diseases. Crit. Rev. Microbiol, 28 (4): 371-409

Morse, TD; Nichols, RA; Grimason, AM; Campbell, BM; Tembo, KC; Smith, HV (2007). Incidence of cryptosporidiosis species in paediatric patients in Malawi. Epidemiol Infect. 135:1307-1315.

NPC; ICF International (2014) Nigeria Demographic and Health Survey 2013, Abuja, Nigeria, and Rockville, Maryland, USA: NPC and ICF International.

Ochiai, RL; Acosta, C. J; Danovaro-Holliday, MC; Baiqing, D; Bhattacharya, SK; Agtini, M D, Bhutta, ZA; Canh, DG; Ali, M; Shin, S; Wain, J; Page, AL; Albert, MJ; Farrar, J; Abu-Elyazeed, R; Pang, T; Galindo, CM; Seidlein, LV; Clemens, JD; Domi Typhoid Study Group (2008). A Study of Typhoid Fever in Five Asian Countries: Disease Burden and Implications for Controls. Bulletin of the World Health Organization, 86: 260-268

Oguntoke, O; Aboderin, OJ; Bankole, AM (2009). Association of water-borne diseases morbidity pattern and water quality in parts of Ibadan City, Nigeria, Tanzan. J. Health Res. 11 (4): 189-195

Ohwo, O (2019). Analysis of household's vulnerability to waterborne diseases in Yenagoa, Nigeria. J Water Sanit Hyg Dev. 9 (1): 71-79

Saad, NJ; Lynch, VD; Antillón, M; Yang, C; John, A; Crump, JA; Pitzer V. E (2018).Seasonal dynamics of typhoid and paratyphoid fever. Sci. Rep, 2018. 8: 6870

UNICEF; PHG (2010).Water, Sanitation and Hygiene Household Survey, Gaza. [Online] https://www.unicef.org/oPt/FINAL_ WASH_REPORT.pdf (accessed March 31, 2018).

UNICEF; WHO (2015). 25 Years Progress On Sanitation And Drinking Water: 2015 Update and MDG Assessment, 2015. [Online] files. unicef.org/.../ Progress_on_

Sanitation_ and Drinking__Water_2015_Update_pdf (accessed August 27, 2016).

UNICEF and WHO (2019), Progress on Household Drinking Water, Sanitation and Hygiene 20002017, Special Focus on Inequalities. New York, USA 
WHO (2017). Diarrhoeal Disease: Key Facts, https://www.who.nt/news-room/factsheets/detal/darrhoeal-disease

WHO (2019). Drinking-water Key Facts, [Online] https://www.who.int/news-room/fact-

sheets/detail/drinking-water (accessed, October 13, 2020)

WHO; UNICEF (2017). Joint Monitoring Program for Water Supply, Sanitation and Hygiene (JMP). https://www.unwater.org/publication categories/whounicef-joint-monitoringprogramme-for-water-supply-sanitation-hygienejmp/
WSP (2012). Economic Impacts of Poor Sanitation in Africa, [Online] https://www.zaragoza.es/ contenidos/medioambiente/onu/825-engv12 pdf (accessed August 7, 2018)

Yallew, WW; Terefe, MW; Herchline, TE; Sharma, HR.; Bitew, BD; Kifle, MW; Tetemke, DM; Tefera, MA; Adane, MM (2012). Assessment of water, sanitation, and hygiene practice and associated factors among people living with HIV/AIDS home based care services in Gondar city, Ethiopia. BMC Public Health, 12, 1057: 1-10

Yilgwan, CS; Okolo, SN (2012). Prevalence of diarrhea and risk factors in Jos University Teaching Hospital, Nigeria. Ann. Afr. Med, 11: 217-221 